Przegląd Badań Edukacyjnych Educational Studies Review

ISSN 1895-4308

nr $30(1 / 2020)$, s. $65-86$

ORYGINALNE ARTYKUŁY BADAWCZE

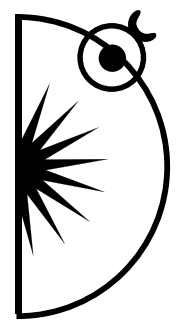

Violetta Kopińska

ORCID: https://orcid.org/0000-0002-5255-9995

Nicolaus Copernicus University, Torun, Poland; e-mail: violetta.kopinska@umk.pl

\title{
The Concept of Citizenship in the Polish School Education. Political Change and the Change of Core Curricula. Discourse Analysis
}

http://dx.doi.org/10.12775/PBE.2020.004

\begin{abstract}
The present article examines the problem of applying the concept of citizenship inherent in the discourse of a political party to core curricula (CCs). The case that provides material for analysis is the coming to power of the conservative party Prawo $i$ Sprawiedliwość [Law \& Justice] (PIS) and the implemented reform of the education system, which entailed the change of CCs. The analytical tool useful for solving the analysed problem is provided by the concept of 'discursive institutionalism' of Vivien Schmidt, integrated with the concept of curriculum analysis, while the method of analysis comes from the group of approaches defined as Critical Discourse Analysis (CDA). The analyses focus on the programmatic level and reveal the application of ideas from the party's programmes to the education objectives articulated in CCs. The findings of the analyses indicate a stronger-than-before emphasis on the idea of a political and national community. Particularly interesting in the analysed case is the focus on the transmission of knowledge, the upbringing according to the values affirming this feeling of community, combined with the simultaneous discursive limitation of the significance of civic participation.
\end{abstract}

Keywords: citizenship; discourse; core curriculum; CDA; institutional change. 


\section{Introduction}

In modern Europe and the US, in an era of increasing nationalism in politics, citizenship is a particularly interesting issue. Political decisions taken by various governments (e.g. refusal of admission of refugees, exit EU) give a clear signal that the vision of citizenship is heading towards an exclusive community. How does this translate into changes in education? The answer to this question is not obvious because in the area of curriculum studies the lack of a linear causation between policy and practice is emphasized (Nordin \& Sundberg, 2018, p. 822).

In 2015, a government formed by a Euro-sceptic and conservative political party, Prawo i Sprawiedliwość [Law \& Justice] (PIS), came to power in Poland. One of the reforms announced by the party was the education reform that entailed the change of core curricula (CCs). The new CCs are being implemented from the 2017-2018 school year. Therefore, I find it interesting to explore which features of the concept of citizenship that are used in the programmatic discourse of the ruling party have been introduced into the CCs. I do not think that a policy prevailing in a given country translates in a straightforward manner into the shape of the core curriculum, but I assume that it is possible for the government policy (of the ruling party) to be implemented in the core curriculum, at least to a certain extent, due to the nature, form and importance of this document (which may vary depending on the country).

The research issues analysed in this article fit with the area of studies demonstrating a connection between policy and education, thus allowing insight into the dynamics of institutional changes. This article presents a portion of studies incorporated in a wider research project aimed at exploring the dynamics of discursive changes with regard to the concept of citizenship in school CCs after 1989.

The article starts with the description of citizenship concepts that will constitute the point of reference for the conducted analyses. I will then describe the research methodology and present the research findings.

\section{The concepts of citizenship}

Today citizenship is understood as a multi-level construct, which goes far beyond narrow, formal and legal meaning (Isin \& Turner, 2002). I believe that there can be no single meaning of citizenship. It is a construct differentiated due to the identity of individuals, their social position, cultural assumptions, institutional practices and a sense of belonging (Werbner \& Yuval-Davis, 1999). Neverthe- 
less, in the research presented in this article, I want to look at citizenship in the perspective of the dominant model that refers to the vision of citizenship expressed in the policy of the ruling party, including education policy. Noting that the relationship between the construction of politics and its implementation in the form of constructing a CCs is not linear (Nordin \& Sundberg, 2018 p. 823), I recognize that in the area of school education the concepts of citizenship promoted by the state are, to some extent, articulated in CCs.

The following concepts of citizenship have been selected as the points of reference for the analyses presented in this article: liberal, civic republican, and critical (Hoskins \& Kerr, 2012). This selection was based on the fact that these concepts influenced the construction of citizenship across Europe (Hoskins \& Kerr, 2012). I assume that the liberal and civic republican concepts will be particularly useful, because the studies of Abowitz and Harnish (2006) indicate that these concepts dominate in the discourse concerning citizenship and civic education. The Polish social and political context is also very important. Political change in Poland brought about a change in the governmental discourse with regard to the vision of citizenship. I perceive this change as a shift towards conservatism in the field of personal freedom.

The liberal model of citizenship is based on the thin conception of democracy (Groot \& Veugelers, 2015). According to this model, individuals have the right to political participation or non-participation (Hoskins, Saisana \& Villalba, 2015, p. 433). From the discourses which are among this concept of citizenship, it can be inferred that values, identity, and forms of democratic participation are not fundamentally agreed here. Rather, it is about focusing on procedures that will be fair and inclusive (Abowitz \& Harnish, 2006, p. 662). What is exposed in the liberal concept is autonomy. Citizens are to be free, self-determined, and responsible in the exercise of their rights and obligations (Abowitz \& Harnish, 2006, p. 662). The concept of individual rights also implies promoting respect for the rights of others (Abowitz \& Harnish, 2006, p. 661). It is a thin concept, but it does not exclude tolerance, freedom, and equality. Its thin nature is rather due to the fact that it defines the framework rather than its content (McLaughlin, 1992, p. 240). Patriotism within this concept is combined with the idea of freedom and equality, and the perspective of many nationalities, cultures, and ideologies is an integral part of it. This is not about civil love and blind loyalty but about evaluative judgement (Abowitz \& Harnish, 2006, p. 666). Within the liberal citizenship model, further divisions are indicated, e.g. neoliberal citizenship, deliberative democracy citizenship (Keating, 2014; Abowitz \& Harnish, 2006). 
The civic republican model of citizenship focuses on the need for political involvement in the public sphere, in particular at the national level (Hoskins et al., 2015, p. 433). Civic participation is understood here in terms of duty as this concept emphasizes responsibility for the common good (Hoskins et al., 2015, p. 433). The responsibility itself is contrasted with a right. As indicated by Abowitz and Harnish (2006), participation in the community is exclusive here (p. 657). This is the element that definitely distinguishes this concept from others. The priority is the political and national community, not universal values and humanistic ethics (pp. 657-690). The civic republican model emphasizes dedication to the community (its goals) and respect for its symbols. Patriotism is understood as love for the country, respect and loyalty to it, but also acting for the common good (Abowitz \& Harnish, 2006, pp. 657-658).

The critical model of citizenship, like the civic republican one, focuses on the involvement of citizens but unlike the civic republican vision, is not about an exclusive community. Inclusion, openness to diversity, critical analysis of social problems, strengthening equality in society through social and political activities, and social justice are the pillars of this model (Westheimer \& Kahne, 2004, pp. 4, 27; Abowitz \& Harnish, 2006. p. 671; Hoskins et al., 2015, p. 434). Nevertheless, it must be noted that considering the findings of studies conducted by Banaji et al. (2018), it is hard to expect that school education will have the features of the critical concept of citizenship.

The concepts of citizenship are embedded in cognitive paradigms and normative frameworks. Their shape is also influenced by the historical background. They are represented and maintained, but also changed, by discursive practice. They are also subject to unification at an international level, which makes them move away from their roots; while their elements, chosen selectively, create a framework that legitimizes specific policies. This is how the 11 September 2001 terrorist attacks in the US and the arrival of a very large number of refugees and immigrants to Europe starting from 2015 created the opportunity to use the discourse of threat. This, in turn, allowed the legitimization of a policy that emphasizes a community that is conservative and exclusive, as well as the reinforcement of nationalist tendencies.

\section{Methodology}

The analytical tool useful for finding the answer to the analysed scientific problem is provided by the concept of 'discursive institutionalism' developed by Vivien Schmidt (2008). This concept is embedded in social constructivism. 
According to Schmidt, institutions are social and cultural constructs. They are simultaneously created and maintained, but also changed, by social actors. Institutional structures have, therefore, both constraining and enabling effects (Schmidt, 2008, pp. 313-314). The discursive approach makes it possible to explain how ideas are represented and how they are provided specific content, but also how they are changed by discourse (Schmidt, 2008, pp. 309-313). This provides insight into the dynamics of institutional changes.

The ideas that constitute the basis of the institutional discourse are shaped at three levels: philosophies, programmes, and policies (Schmidt, 2008, pp. 306-308).

The first level is policy level. It encompasses the 'policy solutions' proposed by policy makers (Schmidt, 2008, p. 306). The second level is programmatic level. This level concerns 'programmatic beliefs' that operate in the space between worldviews and specific policy solutions (Schmidt, 2008, p. 306). This is the level of foreground ideas that create the legitimizing framework ("normative foreground ideas') or indicate the ways of solving various problems by promoting specific solutions ('cognitive foreground ideas') that lead to changing or maintaining the status quo (Schmidt, 2008, p. 307). The third level - 'public philosophy'- is a level of backgrounds ideas that may be normative or cognitive in nature (Schmidt, 2008, pp. 306-307). They are often not articulated and are rarely questioned. They are taken for granted and limit alternative policy choices. Being hard to overcome, they hinder change (Campbell, pp. 22-23). Cognitive paradigms and normative frameworks may account for changes in the policies of individual countries; however, it is hard to overlook that many are transnational in nature (Campbell, pp. 25-26).

Wahlström and Sundberg (2017) pointed out the analogy between the above-described levels of forming ideas and the levels of analysing school curricula in curriculum studies. Thus, the third level corresponds to the societal level, the programmatic level to the actual curriculum level, and the level of policy solutions to the municipal level (in relation to those countries where relative autonomy of the local government authorities is maintained with regard to shaping the educational policy) and/or the classroom level. This is how Wahlström and Sundberg (2017) integrated discursive institutionalism with 'curriculum theory', creating an analytical tool for studying changes with regard to reforming education. It should be pointed out that the levels of analysis indicated in the curriculum theory are not merely the equivalents of the levels of forming ideas in the institutional discourse. By integrating both concepts in the analyses of programmatic changes, it is also possible to internally differentiate the levels 
of these analyses, which enables an in-depth analysis of the top-down discursive formation of ideas (both cognitive and normative), and, as a result, allows insight into the dynamics of changes. This article focuses on the programmatic level. I identify several stages of analysis, as presented in Figure 1.

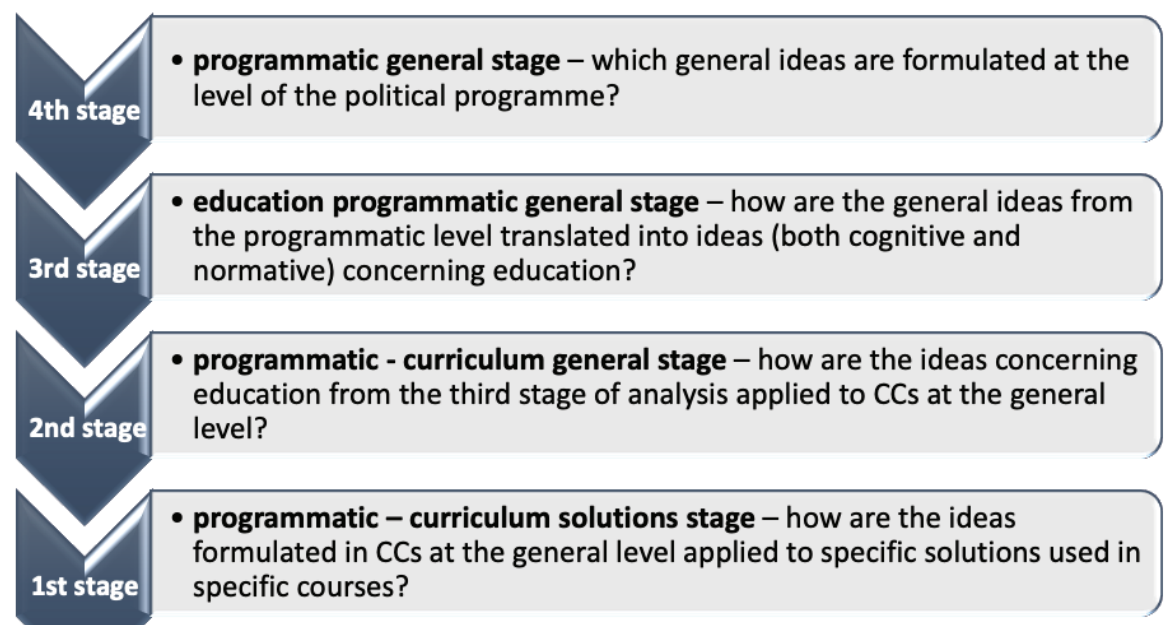

Fig. 1. Order of analysis with regard to applying ideas from the political discourse to the curriculum - stages of analysis at the programmatic level.

Source: Author's study.

The breakdown of the stages of analysis requires a commentary. First, the initial two stages have been adjusted to the structure of the CCs in Poland (Fig. 2), which means that in the case of a different structure, these stages may be combined or additionally differentiated.

Second, identifying the stages of analysis (like previously the levels of analysis) does not imply a linear causation between policy and educational practice, but rather a type of organization. Modern policy, including the educational policy, is subject to transnational influences. It cannot be expected that ideas formulated at the general level determine in a straightforward manner the discursive shape of ideas applied to specific solutions, even when analysed at the programmatic level. Transnational influences are present at the level of cognitive paradigms and normative frameworks, as well as at other, more detailed, levels. This also applies to the educational policy. As a result, these influences 


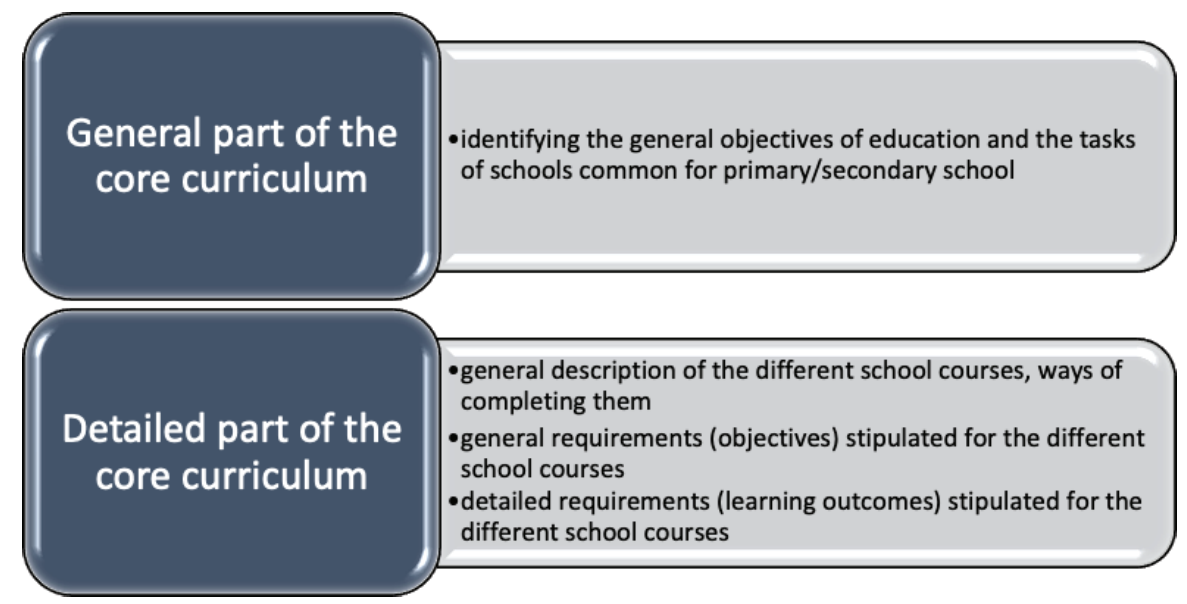

Fig. 2. Structure of core curricula in Poland.

Source: Author's compilation.

may reinforce or weaken certain ideas. They may also limit the scope of possible changes unless the policies are reframed (Campbell, 2002, p. 27). On the other hand, it should be noted that the influences of the transnational policy are subject to 'translation' (Steiner-Khamsi, 2013), that they 'collide' with the historical, economic and social context of the given country and are subject to institutional filtering (Campbell, 2002, pp. 30-31). Having these limitations in mind, I still assume that the current policy pursued by the ruling party influences, to a certain extent, the shape of the educational policy. In Poland, CCs are enacted by the Minister Edukacji Narodowej [Minister of National Education] in the form of a generally applicable legal act, and their implementation is controlled by a set of legal regulations in the area of the education law, which concern, inter alia, the teaching supervision, assessment and examination.

Due to the limited length of the article, the analyses presented herein encompass the fourth, third and second stage of analysis, as per Fig. 1. An analysis encompassing the first level (Fig. 1), i.e. referring to the detailed part of the core curriculum (Fig. 2), is not possible. Due to the degree of accuracy of CCs in Poland (thousands of detailed requirements), it requires a separate study. The limited length of the article makes the presentation of justification for the conclusions impossible, which, in turn, excludes the legitimacy of presenting them herein. Therefore, I decided to limit the presentation of analyses to the fourth, third and second stage (Fig. 1). 
The analyses focus on the concept of citizenship. It constitutes an indirect link between the public philosophy and the programmatic level. It determines the scope of the conducted analyses and constitutes a point of reference with regard to the assessment of the dynamics of changes that the ideas from this level are subject to. The question about implementing the concept of citizenship present in the discourse of the ruling party is a question about the dynamics of changes, from the programmatic general stage down to the solutions at the level of CCs. This required taking the following actions:

(1) exploring which ideas are articulated in the programmatic discourse of the ruling party and how they are articulated - discourse analysis of the party's political programmes from 2014 (PIS, 2014) and from 2019 (PIS, 2019) (4th stage), which will enable the reconstruction of the features of the citizenship concepts present in the programmatic discourse of the ruling party;

(2) exploring how the normative ideas articulated in the party's programmes translate into the ideas concerning education; and specifically: how does the concept of citizenship reconstructed on the basis of the analysis of the normative ideas contained in the ruling party's programmes translate into the concept of citizenship reconstructed on the basis of the ideas concerning education - analysis of the party's programmes with regard to their content concerning education; analysis of texts placed on the website of the Ministerstwo Edukacji Narodowej [Ministry of National Education] (MEN) in the tab 'Education reform' (MEN, n.d.) and of the document containing answers to questions directed to MEN regarding education reform, published on this website (MEN, 2017) (3rd stage);

(3) exploring how the ideas from the third stage of analysis are applied to the general objectives of education contained in CCs, and specifically: how the concept of citizenship reconstructed on the basis of the analysis of the ideas concerning education, contained in the party's programmatic discourse, translates into the concept of citizenship reconstructed on the basis of the general objectives of education articulated in CCs? - analysis of the general part (Fig. 2) of CCs (MEN, 2017a, 2018), also in comparison to the previously applicable CCs (MEN, 2012; 2012a) (2nd stage).

The applied method of analysis comes from the group of approaches defined as Critical Discourse Analysis (CDA) (Wodak, 2001). I researched the application of discursive strategies (nomination, predication, argumentation, intensification/mitigation ${ }^{1}$ ), described by Wodak and Reisigl (Reisigl \&Wodak,

${ }^{1}$ Research questions connected with the application of the discursive strategies at subsequent stages of analysis are formulated in Sections: 4.1., 4.2. and 4.3. 
2001; Wodak, 2001a). Discursive strategies constitute ,a more or less accurate and more or less intentional plan of practices including discursive practices adopted to achieve a particular social, political, psychological and linguistic aim" (Wodak, 2001a, p. 73).

\section{Research findings}

\subsection{The concept of citizenship in the discourse of the ruling party - 'Programmatic General Stage'}

The following ideas are articulated in the discourse of the programmatic documents of the PIS party: the right to life/the protection of life, freedom, solidarity, equality, justice, community, nation. In democratic conditions, these ideas are rarely questioned and are classified as 'normative background ideas'. Particularly significant for capturing the features of the concept of citizenship present in this discourse is, however, pointing out the manner of formulating the content of these ideas at the programmatic level (foreground ideas). In the discourse analysis, I focus on finding the answers to the following questions: How is the given idea introduced? How is its content constructed? Is it evaluated?? With the use of what valuing predicates? What arguments are used to try to justify possible cases of predication? Are these statements formulated openly? Are they intensified? Alternatively, are they mitigated? And finally, which of these ideas are particularly emphasized?

What is clearly emphasized in the analysed documents is the idea of the 'nation'. Positive valuing predicates are assigned to the nation, such as: the most important community (besides family) (PIS, 2014, p. 8), an effective foundation of democratic political communities (PIS, 2014, p. 9). The nation is referred to as a community of 'culture, language, historical experience, political tradition and civilization values, and of the lived life' (PIS, 2014, p. 9). National origin is also affirmed (PIS, 2014, p. 9). The universality of national origin is underlined. Strong value judgements are communicated in this regard, because universality is understood not only as a reference to universal ideas, such as freedom, equality and respect for the human life, but also as a reference to Christianity and the Catholic social teaching-. Universality is also perceived in terms of exceptionality. National origin is exceptional, because the similarity between the Polish experience and the universal message is 'not accidental':

'The universal nature and universal value of the Polish historical and cultural experience is not accidental, just like the unity of the message stemming from Chris- 
tianity is not accidental, which message is part of the Catholic social teaching and the Polish experience' (PIS, 2014, p. 10).

The political identity of the nation is strongly related to the Catholic Church whose nature is 'nation-building' and 'protective' (PIS, 2014, p. 10; PIS, 2019, p. 14). The argumentation supporting such a role is constructed by making references to the history:

'As early as in the Middle Ages, the Church resisted foreign attempts to seize power in Poland; subsequently, it was the clergy that the first authors calling for the recovery of the Republic of Poland came from. In highly unfavourable circumstances of the period of Partitions, just like in the times of the People's Republic Poland, the Church was the mainstay of the Polish identity, it substituted the nonexistent sovereign state.' (PIS, 2014, p. 10).

The above quotation illustrates that strong value judgements are communicated with regard to the role of the Catholic Church. The content of the message is intensified by using specific rhetorical devices. The nouns and verbs used to define the church and its role are very static in nature ('mainstay', 'resisted'). This immovable church is affected by various forces that are characterised by strongly negative expressions, such as 'foreign attempts to seize power', 'highly unfavourable conditions'. The argumentation concerning the role of the church highlights the moral teaching of the church, which is 'commonly known' and which can be only opposed by nihilism (PIS, 2014, p. 11; PIS, 2019, p. 15). The teaching of the Catholic Church combined with the Polish tradition and Polish patriotism build the political identity of the nation (PIS, 2014, p. 10). The state, understood as the democratic state, functions as servant to the nation (PIS, 2014, p. 11; PIS, 2019, p. 15); while democracy is 'successfully supported only in the nation state' (PIS, 2014, p. 11). The argumentation in support of an sovereign nation state also claims that it is the only way to promote the values that are considered fundamental (PIS, 2014, p. 12). Although the documents highlight that being part of the Polish nation is based on birth and cultural heritage (PIS, 2014, p. 9; PIS, 2019, p. 12), the discourse is mitigated by stating that 'A nation shall not be defined on the basis of ethnic origin' (PIS, 2014, p. 9) or by the following statement: 'Although nations have their ethnic core, they constitute primarily a political and cultural community' (PIS, 2019, p. 12). The argument in support of this position refers to the Polish history: 'The Polish nation has been shaped and has matured through the creation of a community of 
people of various ethnic origins' (PIS, 2014, p. 9; PIS, 2019, p. 12). To deepen the understanding of the coordinative discourse with regard to the nation state and national identity, the relationship between the Polish nation and the united Europe should be pointed out. This is connected with further ideas, especially those of freedom, but also of equality and diversity. The diversity of Europeans carries positive value judgements. It is defined as the richness of the continent and civilization, and maintaining it is seen as the only way to ensure Europe's strength and growth (PIS, 2014, p. 12; PIS, 2019, p. 19). However, this diversity does not allow changes within one nation, but rather concerns preserving distinctiveness (PIS, 2019, p. 20) and a traditional model of social life (PIS, 2014, p. 13):

'We want the whole of Europe to be a space of freedom, equality, solidarity and justice, and we think that the model of social life founded on the values of our tradition, when implemented, may exert significant impact through setting a good example. At the same time, we are opposed to all activities aimed at cultural unification. This is our credo for Europe - the continent of cultural diversity.' (PIS, 2014, p. 13; PIS, 2019, p. 20).

What is meant here is not a diversity within one country:

'Europe has witnessed a pursuit of replacing the nations with a multicultural society; European integration is wrongly perceived as the act of building a new European identity supposed to replace the national identities. We reject such manner of perceiving the European community.' (PIS, 2019, p. 12)

The analysed documents also state the rejection of political correctness understood as 'a constraint that more and more painfully affects many Europeans', which is imposed through 'cultural aggression' by means of 'administrative actions and penal repressive measures' (PIS, 2014, p. 13; PIS, 2019, p. 20).

The idea of equality also carries positive value judgements. It is defined as the basis of human dignity and freedom (PIS, 2019, p. 9). What is invoked in this regard is the equality of humanity, civic equality, equality before the law, equality of rights and duties (PIS, 2019, p. 9), but it is also related to economic issues (PIS, 2014, p. 8). The justification for the requirement of equality is the Catholic social teaching, and the discourse is intensified by invoking war crimes (PIS, 2019, p. 9). This idea assumes a distinctive character in the following passage: 
'Neither does equality (...) mean the acceptance of the ideology that $<<$ every choice is equally good $>>$ and every lifestyle equally laudable. We reject relativism and appreciate the pursuit of ideals and perfection in various aspects of social life.' (PIS, 2019, p. 9)

Although the programmatic documents mention the understanding of freedom as personal freedom, the central focus is placed on freedom understood from the perspective of the state and independence (PIS, 2014, pp. 7, 9-10). In the argumentation supporting a positive evaluation of this idea, references to the history of Poland (the Second Republic of Poland) and to Christianity (PIS, 2014, pp. 9-10) are repeated. At the same time, a vision of threatened freedom is created, not only through references to history, but also through references to the relations with the EU:

'We do not accept an uncontrolled erosion of sovereignty of the European countries. We will strongly defend our freedom, by introducing strong legal barriers against the possibility of employing such practices with respect to Poland. This is our Euro-realism' (PIS, 2019, p. 20).

Such discourse is intensified by an image of Poles as a nation with 'a special predilection for freedom' (PIS, 2019, p. 6) and a nation that remembers 'the painful past experiences' (PIS, 2019, p. 8). This is supposed to constitute an argument for opposing 'social engineering' and 'harmful ideologies interfering with social structures' (PIS, 2019, p. 8).

Family also carries positive value judgements. It is defined as the 'basic structure of social life', 'a lasting relationship between a woman and a man', 'the foundation of civilization', in which 'the similarity between the Catholic teaching and national tradition is reflected' (PIS, 2019, pp. 8, 10). Strong positive valuing predicates are assigned to the family, such as: 'a special good', 'irreplaceable', 'particularly valuable', and when referring to the country's history - 'the mainstay of national identity' (PIS, 2014, p. 10). The argumentation referring to the positive evaluation of the family concerns satisfying the needs for closeness, but, above all, fulfilling the function of reproduction and upbringing (PIS, 2014, pp. 8-9; PIS, 2109, p. 11). 'Gender ideology' is identified as a threat to the family. It carries negative value judgements, because its influence concerns the 'spread $<$ build-up $>$ of dismissive attitudes towards establishing families and having children' (PIS, 2014, p. 14; PIS, 2019, p. 11). The negative image of the gender ideology is highlighted by stating that this ideology is be- 
ing artificially popularised and financed from external sources (PIS, 2014, p. 14; PIS, 2019, p. 11).

The coordinative discourse used in the programmatic documents of the ruling party bears similarities to the civic republican concept of citizenship. This concerns primarily the exclusive nature of the community. A reference to universal values, such as freedom and equality, is made, but the discourse analysis indicates that their content is conservative. A political and national community is a priority, and values have very specific content - they are rooted in and simultaneously justified by the Polish history and the Catholic social teaching. These two elements constitute the basic framework for legitimising specific content of the programmatic ideas. The topos of threat used in the analysed discourse and the associated need of resistance and of defending the community are also characteristic of modern nationalist tendencies present especially in the European and the US policies. The threat is identified at the state level (threat from the EU to the sovereignty of the country), the cultural level (threat to values in the traditional sense of the term), including the religious level (threat to the status of the church); the response to the threat is the discourse of resistance and defence, justified by tradition and cultural heritage, and intensified by the glorification of the importance of the Polish nation. Contrary, however, to the civic republican vision of citizenship used in the global discourse, civic participation is not emphasized in this case. This notion is completely excluded. Nevertheless, the notion of 'social energy' is mentioned marginally among the fundamental principles and values, which energy will 'be released' following the limitation of 'pathologies' and the 'recovery of the state' (PIS, 2014, p. 14; PIS, 2019, p. 18). It is not clear, however, towards what this energy should be directed, which makes it hard to assess whether civic participation is meant here at all, not to mention the evaluation of the shape of such participation. Responsibility and sacrifice to the community are also not sufficiently emphasized among the fundamental principles and values described in the programmatic documents. They are mentioned only in the context of the right to life/the protection of life. 'The responsibility for the world around us' is related to the problem of euthanasia, eugenics and abortion (PIS, 2019, pp. 6-7); while sacrifice means sacrificing life or the readiness to sacrifice life in defence of others, and it applies to soldiers, firemen, policemen and other public officers (PIS, 2014, p. 7; PIS, 2019, p. 7). 


\subsection{The concept of citizenship in the programmatic discourse concerning education - 'Education Programmatic General Stage"}

How does the concept of citizenship present in the discourse of the programmatic documents of the ruling party, articulated at the level of normative foreground ideas, translate into the ideas concerning education? To answer this question, it is necessary to conduct a discourse analysis of the documents developed by the party and the government, with a focus on finding the answers to the following questions: How is citizenship education presented, what is its content? Is it evaluated? Are any specific areas of this education evaluated? What arguments are used to try to justify possible cases of predication? Can any cases of intensification/mitigation in analysed texts be identified?

First of all, it must be underlined that the analysed texts, when referring to education in normative aspects, focus primarily on citizenship education. This strategy results in emphasizing the importance of citizenship education and patriotic upbringing.

'A good school - let us come back to the basics - transfers knowledge and skills, contributes to the mental formation, familiarizes young people with the culture code that the Polish nation has developed in its works, educates on how to live in a community, promotes the adequate moral and civic behaviour, provides intellectual and spiritual tools for not only a deeper understanding of today's world, but for a bold and thoughtful participation in it.' (PIS, 2014, p 129)

The parts of the party's programmes which are not connected with citizenship education or patriotic upbringing take little space and contain little detail, which makes them seem less important.

The argumentation in support of a significant role of citizenship education refers to the idea of freedom and sovereignty:

'A free and sovereign Poland depends on the existence of free and sovereign Poles, i.e. such Poles whose minds have been adequately prepared for freedom and sovereignty through educational formation.' (PIS, 2014, p. 129)

What must be noted in this context is the instrumental role attributed to education, its 'influential' nature, the fact of the subjects of education (learners) being described in passive terms and being objectified, which seems to be 
mitigated by the idea of freedom. Nevertheless, considering the content of the idea referred to in section 4.1., it is hard to treat this as an example of applying the mitigation strategy.

The content of citizenship education, which can be reconstructed on the basis of the analysed documents, corresponds to the civic republican model of citizenship education to the extent in which it focuses on preserving traditions and transmitting national heritage, as well as emphasizing the country's history (Abowitz \& Harnish, 2006, pp. 657, 659):

'The graduates of Polish schools should share a common set of knowledge, the knowledge of common symbols, references, concepts, which constitute the foundation of the Polish identity and form the experience of our nation. Therefore, the importance of courses such as literature and history will be restored (...)' (PIS, 2014, p. 129)

'Shaping the feeling of national and state identity will be a permanent and important element of the agenda of the Polish school. The right selection of the required reading list, besides the cognitive and intellectual value, will enable the maintenance of a common culture code connecting subsequent generations of Poles. Teaching respect for tradition and national heroes as well as celebrating national holidays will constitute an important element of educating the young generation.' (PIS, 2019, p. 134)

Such education also emphasizes duties, the responsibility for the community (as opposed to the attitude to 'unlimited consumerism and egoism'), and focuses on values and knowledge (to prevent the 'fragmentation of the minds of young people') (PIS, 2014, p. 131) that ensures civic literacy (PIS, 2019, p. 134).

As in the case of the texts concerning ideas and fundamental values, civic participation is not emphasized. Although a 'bold and thoughtful participation in the world' (PIS, 2014, p. 129) and the 'citizen's duty to co-shape the community' (PIS, 2019, p. 134) are mentioned, it is hard to conclude the shape of this participation. The statement 'We will cultivate the attitudes of helping others to raise simply good people' (PIS, 2019, p. 134) suggests a participation understood from the perspective of the model referred to by Westheimer and Kahne (2004) as 'personally responsible', which seems to be not fully in line with the ideas of the civic republican model of citizenship education, but it is hard to make unequivocal assessments in this regard.

Additional distinctive features are attributed to the already-mentioned idea of equality. In the discourse concerning education, the exclusivity of education 
is underlined. On the one hand, declarations such as 'We want every learner, irrespective of where they live or what is the financial status of their family, to be able to receive education from a good school and have access to good education' (MEN, n.d.) are made; and on the other hand, moving towards elitist education is visible: 'This puts an end to an era of 'lowering the standards', and the curriculum is adjusted to the capabilities of talented learners' (PIS, 2019, p. 131) or it is stated that 'in case extreme pathologies occur among learners', the 'destructive influence of such learners on the classroom community and (...) the threat to the teachers' will be eliminated by placing them in centres established for this purpose.

\subsection{The concept of citizenship in CCs - 'Programmatic - Curriculum General Stage'}

How is the concept of citizenship identified at the preceding stage of analysis being applied to CCs, and more specifically - how does it translate into the general objectives of education, formulated in the general part of CCs (Fig. 2)? To answer this question, it is necessary to not only analyse the relevant parts of the new CCs that are being implemented in Polish schools as part of the education reform from the 2017-2018 school year, but also compare the analysed texts with the previously applicable CCs. It must be underlined in this regard that the change of CCs in Poland did not entail changing the structure of these documents. The structure has remained unchanged and it complies with the European standards of education that is based on 'knowledge standards' and testing; therefore, it uses the language of the learning outcomes. However, both in the previous CCs and in the newly implemented ones, the objectives of school education have been articulated in the introductory parts of the document and a comparison of these parts provides insight into a discursive change concerning the communication of education objectives as a result of the introduced reform. The analysis in this section will, therefore, focus on finding the answers to the following questions: How have the education objectives changed in the new CCs as compared to the previous ones? What image of citizenship education can be reconstructed on the basis of these objectives? Is citizenship education evaluated? Are any specific areas of this education evaluated? What arguments are used to try to justify possible cases of predication? Can any cases of intensification/mitigation in analysed text be identified?

The analysis proved that the education objectives in the new CCs have been modified to strengthen and emphasize the importance of knowledge and 
values in the education process. With respect to values, this is particularly visible in the core curriculum for primary school (the first eight years of education) (MEN, 2017a). In this regard, the previous reference to the attitudes such as integrity, reliability, perseverance (MEN, 2012, 2012a) is replaced by a reference to the values that support the civic republican concept of citizenship due to being relevant for the functioning of the community, such as: dedication, solidarity, altruism, patriotism, identifying good behaviour and building social relationships (2017a). Instead of a general reference to responsibility, the responsibility for the community is mentioned (MEN, 2017a). The following passage found in the previous CCs:

'In social development, it is extremely important to shape a citizenship attitude, an attitude of respect for the tradition and culture of one's own nation, and an attitude of respect for other cultures and traditions. The school takes the relevant steps to prevent any discrimination.' (MEN, 2012, 2012a)

has been replaced with a different one:

'Education and upbringing in primary schools (in general secondary schools and technical secondary schools) fosters the development of citizenship, patriotic and social attitudes of learners. The school's task is to reinforce the feeling of national identity, attachment to history and national traditions, to prepare for and encourage to taking actions supporting the school and local environments, including involvement in voluntary service. The school cares for the upbringing of children and youth in the spirit of acceptance and respect for the other human being [...]' (MEN, 2017a, 2018).

The analysis of these two passages indicates a discursive change with regard to the concept of citizenship. Shaping an attitude of respect for the tradition and culture of one's own nation is replaced by a reinforcement of the feeling of national identity, attachment to history and national traditions. Thus, stronger emphasis is placed on national identity. This exclusivity is mitigated by a 'spirit of acceptance' and an 'attitude of openness'. It should be underlined that in the new CCs, counteracting any discrimination and 'respect for other cultures and traditions' are excluded from the discourse, although with regard to the latter attitude, 'respect for the other human being' (MEN, 2017a) and respect for others (MEN, 2018) are mentioned elsewhere in the newly implemented CCs. The context for the interpretation of these changes may be the content of the idea of equality and freedom reconstructed on the basis of the programmatic discourse at the fourth stage of analysis (see Section 4.1). In the light of the comments 
contained therein, this change can be interpreted as a measure to avoid using an expression that can be seen as liberal, but not give up on a reference to the principle of universal ethics (respect for the other human being is not questioned). This measure may be a method of legitimizing the normative discourse concerning the national community.

The conservative nature of the citizenship concept reconstructed on the basis of the analysis of the education objectives is also underlined by emphasizing the 'will of parents' in the school's operations (MEN, 2017a, 2018).

In contrast, social participation has never been, and still is not, emphasized in CCs. The new CCs do not mention the duty of participation, although they state the need to 'prepare for and encourage to taking actions supporting the school and local environments, including involvement in voluntary service' (MEN, 2017a, 2018). Participation is not defined as a duty, which is characteristic of the liberal concept of citizenship. Moreover, the suggested form of participation seems to be getting depoliticised and to acquire the features of functionality, as described by Biesta (2009), which, on the one hand, may stem from transnational influences, and, on the other hand, may be the effect of a collision with a specific social context.

A positive value judgement of the citizenship education in CCs results primarily from emphasizing among the objectives of school education the values that fit with its shape.

The arguments supporting a set of education objectives formulated this way are twofold. The first one is integral development (MEN, 2017a, 2018). This argument, which was also included in the previous CCs (although the development was not referred to therein as 'integral', but 'harmonious', indicating its different areas $<$ MEN 2012 $>$, or 'comprehensive' $<$ MEN 2012a $>$ ), may be surely understood as a reference to the liberal thinking about school. The second argument has been introduced as a result of changes. It concerns the 'fulfilment of the fundamental objectives of the educational policy', which include 'the school's upbringing activities'. As stipulated in the CCs: 'The school's task is to direct the upbringing process towards the values that set the objectives of upbringing and the criteria of its evaluation.' (MEN, 2017a, 2018).

\section{Conclusions}

The analyses presented in this article indicate that the idea of a political and national community that is most strongly highlighted in the programmatic discourse of the ruling party has been implemented at the level of the general 
objectives articulated in the new CCs. In the educational area, this has been translated into emphasizing in the normative discourse the citizenship education understood as one that strongly (more strongly than before) shapes the national identity and assumes upbringing according to the values affirming this feeling of community. These features fit with the civic republican concept of citizenship. The exclusivity of this community is mitigated by references to universal values, although the discursive modifications in this regard raise doubts as to the manner of understanding these values, especially if we interpret them in the context of their content articulated in the party's programmatic documents. It should be also noted that the texts analysed in the general part of core curricula do not use the topos of threat and the associated need of resistance and of defending the community, which are clearly visible in the programmatic discourse at the fourth stage of analysis (see Section 4.1). What is also missing in CCs is the references to Christianity, to the Catholic Church and the emphasis on the uniqueness of the Polish nation. Thus, the argumentation in support of emphasizing and affirming the national identity disappears, although the associated values and objectives remain unchanged. Such a discursive change may stem from the specific features of the genres that the analysed texts represent. The party's programmatic texts are addressed to the voters, which means that they need to contain argumentation to justify the placement of emphasis on specific ideas. The same applies to the programmatic texts of the party or the government concerning education. CCs do not constitute a commonly known document. Moreover, they are addressed to schools and they use the indicative mood to communicate the objectives and tasks of schools. Not only is persuasion unnecessary in such documents, but there is no room for it. Therefore, it seems interesting to move to the next stage of analysis, which will enable the comparison of the general objectives attributed to education in CCs with the solutions at the level of individual courses. Reconstruction of the citizenship concept on the basis of the discourse analysis of the detailed part of CCs (Fig. 2) may reveal the changes that the declarative ideas are subject to following their translation into the language of education. This is where, in my opinion, the 'collision' with transnational influences will be particularly visible. The preserved structure and nature of CCs result from a specific educational policy and they do not put emphasis on the shaping of attitudes. This is confirmed by the analyses of the Polish CCs, according to which the CCs focus primarily on the learning outcomes associated with the area of knowledge, even if we analyse only those learning outcomes that are related to the development of the social and civic competence (Kopińska, 2019, pp. 183-184). As a consequence, the application 
of the general objectives of education to the language of the learning outcomes may bring about a significant modification. What are the dynamics of the idea of an exclusive national community and civic participation in the discourse of the learning outcomes attributed to individual school courses? This question shall be the subject of further research.

\section{References}

Abowitz, K. K., \& Harnish, J. (2006). Contemporary Discourses of Citizenship. Review of Educational Research, 76(4), 653-690, doi: 10.3102/00346543076004653.

Banaji, S., Mejias, S., Kouts, R., Piedade, F., Pavlopoulos, V., Tzankova, I., Mackova, A., \& Amnå E. (2018). Citizenship's Tangled Web: Associations, Gaps and Tensions in Formulations of European Youth Active Citizenship Across Disciplines. European Journal of Developmental Psychology, 15(3), 250-269, doi: 10.1080/17405629.2017.1367278.

Biesta, G. J. J. (2009). What Kind of Citizenship for European Higher Education? Beyond the Competent Active Citizenship. European Educational Research Journal, 8(2), 146-158, doi: 10.2304/eerj.2009.8.2.146.

Campbell, J. L. (2002). Ideas, Politics, and Public Policy. Annual Review of Sociology, 28, 21-38, doi: 10.1146/annurev.soc.28.110601.141111.

Groot, de I., Veugelers, W. (2015). Why We Need to Question the Democratic Engagement of Adolescents in Europe. Journal of Social Science Education, 14(4), 27-38, doi: 10.2390/jsse-v14-i4-1426.

Hoskins, B., \& Kerr, D. (2012). Final Study Summary and Policy Recommendations Report: Participatory Citizenship in the European Union. Institute of Education Report for EU. Southampton: University of Southampton.

Hoskins, B., Saisana, M., \& Villalba, C.M.H. (2015). Civic Competence of Youth in Europe: Measuring Cross National Variation Through the Creation of a Composite Indicator. Social Indicator Research, 123, 431-457, doi: 10.1007/s11205-014-0746-z.

Keating, A. (2014). Education for Citizenship in Europe. European Policies, National Adaptations and Young People's Attitudes. Basingstoke: Palgrave-Macmillan

Kopińska, V. (2019). Country Report: Civic and Citizenship Education in Polish School. Journal of Social Science Education, 18(1), 172-202, doi: 10.4119/jsse-1409.

McLaughlin, T.H. (1992). Citizenship, Diversity and Education: a Philosophical Perspective. Journal of Moral Education, 21(3), 235-250, doi: 10.1080/0305724920210307.

MEN [Ministry of National Education] (2012). Załącznik nr 2 do Rozporządzenia Ministra Edukacji Narodowej z dnia 27 sierpnia 2012 r. w sprawie podstawy programo- 
wej wychowania przedszkolnego oraz kształcenia ogólnego w poszczególnych typach szkół, Dz. U. 2012, poz. 977 ze zm. w brzmieniu ustalonym przez Załącznik nr 2 do rozporządzenia Ministra Edukacji Narodowej z dnia 30 maja 2014 r. zmieniającego rozporządzenie w sprawie podstawy programowej wychowania przedszkolnego oraz kształcenia ogólnego w poszczególnych typach szkół, Dz. U. 2014, poz. 803 [Annex no 2 to The Decree of the Minister of National Education of 27th August 2012, concerning the core curriculum of preschool education and general education in individual types of schools, in the wording granted through the Decree of the Minister of National Education of 30th May 2014 changing the Decree concerning the core curriculum of preschool education and general education in individual types of schools, OJ 2014, item 803 - The core curriculum of general education for primary schools].

MEN [Ministry of National Education] (2012a). Załącznik nr 4 do Rozporządzenia Ministra Edukacji Narodowej z dnia 27 sierpnia 2012 r. w sprawie podstawy programowej wychowania przedszkolnego oraz kształcenia ogólnego w poszczególnych typach szkół, Dz. U. 2012, poz. 977 ze zm. [Annex no. 4 to The Decree of the Minister of National Education of 27th August 2012, concerning the core curriculum of preschool education and general education in individual types of schools, OJ 2012, item 977 with changes - The core curriculum of general education for secondary schools and post-secondary schools, finishing of which enables obtaining maturity diploma after passing the $m a$ tura ${ }^{2}$ exam].

MEN [Ministry of National Education] (2017). Answers to questions directed to the Ministry of National Education regarding education reform, Retrieved 28 February 2020 from .

MEN [Ministry of National Education] (2017a). Załącznik nr 2 do Rozporządzenia Ministra Edukacji Narodowej z dnia 14 lutego 2017 r. w sprawie podstawy programowej wychowania przedszkolnego oraz podstawy programowej kształcenia ogólnego dla szkoły podstawowej, w tym dla uczniów z niepełnosprawnością intelektualną w stopniu umiarkowanym lub znacznym, kształcenia ogólnego dla branżowej szkoły I stopnia, kształcenia ogólnego dla szkoły specjalnej przysposabiającej do pracy oraz kształcenia ogólnego dla szkoły policealnej, Dz. U. 2017, poz. 356 [Annex No. 2 to The Decree of the Minister of National Education of February 14, 2017, concerning the core curriculum of preschool education and the core curriculum of general education for primary school, including pupils with moderate or severe intellectual disabilities, general education for technical school of the first degree, general education for vocational school, as well as general education for post-secondary school, OJ 2017, item 356 with changes].

MEN [Ministry of National Education] (2018). Załącznik nr 1 do Rozporządzenia Ministra Edukacji Narodowej z dnia 30 stycznia 2018 r. w sprawie podstawy programowej kształcenia ogólnego dla liceum ogólnokształcącego, technikum oraz branżowej szkoły

2 Equivalent of A-levels in the UK, 
II stopnia, Dz. U. 2018, poz. 467 [Annex No. 1 to The Decree of the Minister of National Education of January 30, 2018, concerning the core curriculum of general education for general secondary school, technical secondary school, and vocational secondary school of the second degree, OJ 2018, item 467].

MEN [Ministry of National Education] (n.d.). Reforma edukacji [Education Reform], Retrieved 15 January 2020 from: https://www.gov.pl/web/edukacja/reforma-edukacji.

Nordin, A., \& Sundberg, D. (2018). Exploring Curriculum Change Using Discursive Institutionalism - a Conceptual Framework. Journal of Curriculum Studies, 50(6), 820-835, doi: $10.1080 / 00220272.2018 .1482961$.

PIS, (2014). Program Prawa i Sprawiedliwości [Law \& Justice Program]. Retrieved 15 January 2020 from: http://pis.org.pl/.

PIS, (2019). Program Prawa i Sprawiedliwości [Law \& Justice Program]. Retrieved 15 January 2020 from: http://pis.org.pl/.

Reisigl M., \& Wodak R. (2001). Discourse and Discrimination. Rhetorics of Racism and Ant-Semitism, London; Routledge.

Schmidt, V. A. (2008). Discursive Institutionalism: The Explanatory Power of Ideas and Discourse, Annual Review of Political Science, 11, 303-326.

Steiner-Khamsi, G. (2013). What Is Wrong with the 'What-Went-Right' Approach in Educational Policy? European Educational Research Journal, 12(1), 20-33.

Wahlström, N., \& Sundberg, D. (2018). Discursive Institutionalism: Towards a Framework for Analysing the Relation Between Policy and Curriculum. Journal of Education Policy, 33, 163-183, doi: 10.1080/02680939.2017.1344879.

Werbner, P., \& Yuval-Davis, N. (1999). Introduction: Women and the New Discourse of Citizenship. In: N. Yuval-Davis, \& P. Werbner (Eds.), Women, Citizenship and Difference (pp. 1-38). London and New York: Zed Books.

Westheimer, J. (2019). Civic Education and the Rise of Populist Nationalism. Peabody Journal of Education, 94(1), 4-16, doi: 10.1080/0161956X.2019.1553581.

Westheimer, J., \& Kahne, J. (2004). What Kind of Citizen? The Politics of Educating for Democracy. American Educational Research Journal, 41(2), 1-30, doi: 10.3102/00028312041002237.

Wodak, R. (2001). What CDA Is About - a Summary of Its History, Important Concepts and Its Developments. In: M. Meyer, \& R. Wodak (Eds.), Methods of Critical Discourse Analysis (pp.1-13). Sage Publications Ltd.

Wodak, R. (2001a). The Discourse-Historical Approach. In: M. Meyer, \& R. Wodak (Eds.), Methods of Critical Discourse Analysis (pp. 63-94). Sage Publications Ltd. 